\title{
Treated with Nitric Oxide Pepper Plant under Drought Stress Proline, Protein Determination of Relative Water Content and Chlorophyll amount
}

\author{
Fikret Yasar (Corresponding author) \\ Van Yuzuncu Yil University, Faculty of Agriculture, \\ Department of Horticulture, Van, Turkey \\ e-mail:fyasar@yyu.edu.tr \\ Ahmet Cengiz \\ Ministry of Agriculture, Food and Livestock, \\ Van Provincial Directorate, Van, Turkey
}

\begin{abstract}
The aim of this study was to determine the possible roles of NO (Nitric Oxide) which has the characteristic of messenger molecule in some metabolic changes under the effect of drought stress in plants and to determine the relationship between proline, protein, proportional water content and chlorophyll amounts. The study was carried out under controlled conditions in 16/8 hour light / dark photoperiod, $25{ }^{\circ} \mathrm{C}$ and $70 \%$ humid climate room. The plants were cultured in containers containing Hoagland nutrient solution. For application of drought stress, 10\% Polyethylene Glycol (PEG 6000) was added to the nutrient solution which corresponds to the osmotic potential of $-0.40 \mathrm{MPa}$. Before applying drought stress, different doses of pepper seedlings sodium nitroprusside (SNP) and potassium salt (carboxy-PTIO) were applied externally after SNP 0.01, SNP 1, SNP 100 and SNP $0.01+$ cPTIO, SNP 1 + cPTIO, SNP. $100+$ cPTIO. Sampling was performed on the 10th day of drought. After the total plant weights were measured, Proline, Protein, Proportional Water Content (OSI), and Chlorophyll content of the leaves of pepper plants were examined in order to clarify the damage mechanism of drought stress and the effect of stress on applications.

In terms of total plant weight, it was observed that the growth and growth of pretreated plants were better with 0.01 and 1 doses of SNP and an increase in Proline, Protein, OSI and Chlorophyll amounts.
\end{abstract}

Keywords: Pepper, Capsicum annum, carboxy-PTIO, Drought stress, Nitric oxide, Proline, Protein, Chlorophyll, SNP

DOI: $10.7176 / \mathrm{JSTR} / 5-10-06$

Not: Bu çalışma Van Yüzüncü Yıl Üniversitesi Rektörlüğü Bilimsel Araştırma Projeleri Koordinasyon Birimi tarafindan desteklenen 2014-FBE-YL035 nolu projeden üretilmiștir.

\section{Nitrik Oksit Uygulanmış Biber (Capsicum annum) Bitkisinin Kuraklık Stresi Altında Prolin, Protein, Oransal Su İçeriği ve Klorofil Miktarlarının Belirlenmesi}

\begin{abstract}
Özet
Deneme materyali olarak Demre sivri biber çeşidinin kullanıldığı çalışmanın amacı bitkilerde kuraklık stresi etkisi altında meydana gelen bazı metabolik değişikliklerde haberci molekül özelliğine sahip NO (Nitrik oksit) in muhtemel rollerini saptamak ve prolin, protein, oransal su içeriği ve klorofil miktarlarıyla arasındaki ilişkiyi tespit etmektir. Çalışma kontrollü şartlardaki 16/8 saatlik aydınlık/karanlık fotoperiyotta, $25{ }^{\circ} \mathrm{C}$ de ve $\% 70$ nemli iklim odasında yürütülmüştür. Bitkiler, Hoagland besin çözeltisi içeren kaplarda kültüre alınmıştır. Kuraklık stresi uygulaması için besin çözeltisine -0,40 MPa ozmotik potansiyele denk olan \%10 oranında Polietilen Glikol (PEG 6000) eklenmiştir. Kuraklık stresi uygulanmadan önce biber fideleri sodyum nitroprussid (SNP) ve potassium salt (carboxy-PTIO)'nun farklı dozları dışsal uygulandıktan sonra SNP 0,01, SNP 1, SNP 100 ve SNP 0,01+cPTIO, SNP 1+cPTIO,
\end{abstract}


SNP 100+cPTIO ile ön muameleye tabi tutulmuştur. Kuraklık uygulamasının 10. gününde örnek alma işlemi yapılmıştır. Toplam bitki ağırlıkları ölçüldükten sonra, alınan örneklerden, kuraklık stresinin zarar mekanizmasını ve uygulamaların strese olan etkisini aydınlatabilmek için, biber bitkilerinin yapraklarında Prolin, Protein, Oransal Su İçeriği (OSİ), ve klorofil miktarları incelenmiştir.

Toplam bitki ağırlı̆̆ bakımından SNP nin 0,01 ve 1 dozları ile ön muamele görmüş bitkilerin gelişimi ve büyümesi daha iyi gerçekleştiği, Prolin, Protein, OSİ ve Klorofil miktarlarında artış görülmüştür.

Anahtar Kelimeler: Biber, Capsicum annum, carboxy-PTIO, Kuraklık stresi, Nitrik oksit, Prolin, Protein, Klorofil, SNP

\section{Giriş}

Dünya bitkisel üretimini sınırlandıran başlıca çevresel stres faktörlerinden dolayı, yetiştiricilikte bitkinin normal ürün potansiyeline ulaşabilecek uygun alanların bulunması oldukça zordur. Bitkiler, hareket edemediklerinden dolayı çevresel koşullardaki değişikliklere ve olumsuz koşullara en fazla maruz kalan canlılardır. Yaşam döngüleri boyunca gerçekleşen kuraklık, tuzluluk, aşırı yağış, sıcaklık veya soğuk gibi iklimsel değişikliklere bağlı abiyotik stres koşulları bitki büyüme ve gelişmesini doğrudan etkilemektedir (Taiz ve Zeiger, 2010).

Bitkiler kurak koşullarla karşılaştıklarında, oluşan stresin süresine ve şiddetine bağlı olarak genetik yapıları gereği hayatta kalma ve nesillerini devam ettirme isteklerinden dolayı metabolik yapılarında köklü ve çarpıcı değişiklikler yapacak şekilde metabolizmalarını yeniden yapılandırabilirler (Yaşar ve ark., 2014).

Bitkilerde kuraklık stresi etkisi altında meydana gelen bazı metabolik değişikliklerden bir diğeri de, haberci molekül özelliğine sahip nitrik oksit (NO) dir. NO, bir nitrojen ve bir oksijen atomundan oluşan, lipofilik, gaz halinde bulunan, reseptöre bağımlı olmadan kolayca difüze olabilen, çok kısa yarı ömürlü, eşleşmemiş elektron içeren, serbest radikal olarak da nitelendirilen, renksiz, inorganik bir moleküldür (Olson ve Garban, 2008).

Nitrik oksit bitkilerde çeşitli fizyolojik fonksiyonları ile önemli bir sinyal molekülüdür. Bitkilerin tohumdan çiçeklenme evresine kadar büyüme ve gelişmesinde, meyvelerin olgunlaşmasında önemli bir rol oynadığı düşünülmektedir. Ayrıca abiyotik ve biyotik faktörlerden kaynaklanan çevresel stresin oluşturduğu tehlike durumunda, NO farklı bitki türlerinde ve organlarında üretilebilmektedir. Nitrik oksit, oksidatif stres koşullarının verdiği zarara karşı çeşitli biyolojik yollarla bitkileri koruduğu kanıtlanan çok aktif bir moleküldür (Carlos ve Lorenzo, 2001). Nitrik oksit bitki hücrelerinde yararlı olduğu kadar zararlı etkiler de yaratabilir. Bu durum nitrik oksidin miktarına bağlıdır. Nitrik oksit hücrelerdeki iyon regülasyonu (Garcı-Mata ve ark., 2003), hücre duvarı ligninleşmesi (Ferrer ve RosBarcelo, 1999), yaşlı hücrelerdeki mitokondriyal ve kloroplastik işlevlerde (Leshem, 1996; Hung ve Kao, 2003), demir birikimi (Murgfa ve ark., 2002), gibi süreçlerde rol oynamaktadır. Nitrik oksit, $\mathrm{H}_{2} \mathrm{O}_{2}$ gibi sinyal moleküllerinin biyolojik etkilerine de aracılık edebilmektedir.

Kurak koşullar, aynı zamanda bitki hücre turgor basıncını yani su potansiyeli miktarını değiştirmektedir. Bitki hücrelerinin su stresinden en az etkilenmelerini sağlamak için ozmotik dengeleme çok önemlidir. $\mathrm{Bu}$ amaçla bitkiler kuraklık stresini algıladıklarında hücrelerinde "ozmolit" olarak isimlendirilen ve hücre turgor dengesinin korunmasında rol oynayan bir grup çözünür madde sentezler ve biriktirirler. Bu maddeler asparajin, prolin ve glisin gibi serbest amino asitler, betain, organik asitler ve karbonhidratlar gibi farklı gruplardan olabilmektedir. Su dengesini korumakla görevli olan ozmolitler bitkinin kuraklık stresine toleransını doğrudan arttırmazlar. Ancak, yaprak su basıncını dengeledikleri için stoma iletkenliğini arttırır, fotosentezin devamlılığını sağlar ve böylece büyümeye yardımcı olurlar. Kurak koşullar oluştuğunda ilk biriken serbest amino asit prolin olduğu için bu molekülün hücre içi konsantrasyonu araştırmalarda gerçekleştirilen deneysel koşullarda bitkilerin su sıkıntısına girdiğini göstermek için sıklıkla kullanılan bir ölçüm değeridir. Prolinin hücre içi temel görevi, lipit oksidasyonunu engelleyerek membran sistemlerini ve oluşturdukları bileşikler aracılığıyla da protein yapılarını korumaktır. Ancak son yıllarda gerçekleştirilen çalışmalar, prolinin aynı zamanda sinyal iletiminde de görevli olabileceğini ve mitokondri fonksiyonlarının düzenlenmesi, hücre bölünmesi veya ölümü ve hatta gen anlatım seviyelerinin düzenlenmesinde de rol oynayan önemli bir serbest amino asit olabileceğini ortaya koymaktadır (Anjum ve ark., 2011; Liang ve ark., 2013; Kishor ve Sreenivasulu, 2014).

$\mathrm{Bu}$ çalışmanın amacı, bitkilerde kuraklık stresi etkisi altında meydana gelen bazı metabolik değişikliklerde haberci molekül özelliğine sahip NO (Nitrik oksit) in muhtemel rollerini saptamak ve 
prolin, protein, oransal su içeriği ve klorofil miktarlarıyla arasındaki ilişkiyi tespit etmektir.

\section{Materyal ve Yöntem}

\subsection{Materyal}

\subsubsection{Bitki materyali}

Biber (Capsicum annum) bitkisinde kuraklık stresi ile nitrik oksit (NO, azot monoksit) arasındaki ilişkinin incelenmesini amaçlayan bu deneme, Yüzüncü Yıl Üniversitesi Bahçe Bitkileri Fizyoloji Laboratuarında yürütülmüştür. SNP ve cPTIO'nun biber bitkisi üzerine etkileri araştırılmıştır. Çalışmada güçlü kök yapısına sahip, hastalıklara dayanıklı, yüksek verimi sahip olan Demre sivri biber çeşidi kullanılmıştır.

\subsection{Yöntem}

Biber tohumları ponza doldurulmuş plastik çimlendirme kaplarına yaklaşık 100 adet tohum ekildikten sonra sulanıp çimlendirmeye bırakılmıştır.

\subsubsection{Biber (Capsicum annuum ) Fidelerinin Yetiştirilmesi}

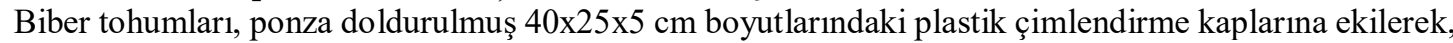
$16 / 8$ saatlik aydınlık/karanlık fotoperiyotta, $25 \pm 2^{0} \mathrm{C}$ sıcaklık $\% 70$ nemde $500 \mu \mathrm{mol} \mathrm{m}^{-1} \mathrm{~s}^{-1}{ }_{1 S ̧} 1 \mathrm{k}$ yoğunluğuna sahip iklim odasına yerleştirilmiştir. İlk gerçek yaprakları görülmeye başlayan fidelerde sulama Hoagland besin çözeltisiyle (Hoagland ve Arnon, 1938) yapılmaya başlanmıștır. Ponza ortamında 2. gerçek yaprakları da oluşan fidelerin ön muamele işlemi kahverengi şişelerde 2 gün boyunca, 1/2 Hoagland çözeltisi içinde hazırlanan $0.01,1,100 \mu \mathrm{M}$ konsantrasyonlardaki Nitrik oksit (NO) vericisi sodyum nitroprussid (SNP) ve Nitrik oksit (NO) yakalayıcısı $1 \mu \mathrm{M}$ cPTIO (potassium salt) [2-(4karboksi-fenil)-4,5-dihidro-4,4,5,5-tetrametil-1H-imidazol-1-oksi-3-oksit] ile yapılmıștır. Daha sonra ön muamele görmüş ve ön muamele görmemiş fideler su kültürü ortamına alınmışlardır. Su kültürü için, Hoagland besin çözeltisi doldurulmuş $25 \times 25 \times 18 \mathrm{~cm}$ boyutlarındaki plastik küvetler kullanılmıştır. Birer haftalık aralarla besin çözeltileri tazelenmiş, bu sırada küvetlerin yerleri de değiştirilerek 1şılanma koşullarından tüm bitkilerin eşit biçimde yararlanması sağlanmıştır.

\subsubsection{Kuraklık stresinin Uygulanması}

Kuraklık stresi uygulanmadan önce 3-4 gerçek yaprağa sahip olan 6 günlük fidelere 2 gün boyunca, 1/2 Hoagland çözeltisi içinde hazırlanan $0.01,1,100 \mu \mathrm{M}$ konsantrasyonlardaki Nitrik oksit (NO) vericisi sodyum nitroprussid (SNP) ve Nitrik oksit (NO) süpürücüsü $1 \mu \mathrm{M}$ c-PTIO (potassium salt) [2-(4karboksi-fenil)-4,5-dihidro-4,4,5,5-tetrametil-1H-imidazol-1-oksi-3-oksit] ile ön muamele yapıldıktan sonra 1 12 Hoagland çözeltisine \% 10 oranında Poli Etilen Glikol (PEG 6000) eklenerek oluşturulan PEG grubuna ve diğer uygulamalara (Kontrol hariç) \% 10 oranında Poli Etilen Glikol (PEG 6000) eklenerek kuraklık stresi uygulanmıştır. Kuraklık uygulamasından sonra 10. günde hasat edilen bitkilerden örnekler alınmıştır.

\subsubsection{Oransal su içeriği (OSİ) tayini}

Her bir stres uygulamasının sonunda çeşit ve hattın 5 farklı yaprağından alınan $1 \mathrm{~cm}$ 'lik yaprak disklerinde oransal su içeriği Farrant (2000)'e göre belirlenmiştir. Çeşitten 3 tekerrürün aynı seviyedeki yaprağı alınıp tartıldıktan sonra saf suyun içinde 5 saat bekletilmiştir. Daha sonra örnekler saf sudan çıkartılıp tekrar tartım yapılmıştır. Numaralandırılan kese kâğıtlarına konulan örnekler 72 saat $70^{\circ} \mathrm{C}$ deki etüve yerleştirilerek kurutulmaya bırakılmış. Üç gün sonra etüvden çıkarılan kuru örnek ağırlıkları bir kez daha tartılmıştır. Bu değerler kullanılarak aşağıdaki formüle göre OSİ hesaplanmıştır.

$$
\text { OSİ=(Taze ă̆. }- \text { Kuru ağ. / Tam Turgor ağ. - Kuru ağ.) x } 100 .
$$

\subsubsection{Klorofil Tayini}

Bitkiden ilk üç yaprak alınarak bu analizler yapılana kadar $-84{ }^{\circ} \mathrm{C}$ deki derin dondurucuda saklanmıștır. $-84{ }^{\circ} \mathrm{C}$ donmuş olan yaprak örneklerinde $200 \mathrm{mg}$ alınarak \%80'lik etanol içerisine konularak $80{ }^{\circ} \mathrm{C} \mathrm{su}$ banyosunda 20 dakika sureyle bekletildikten sonra $654 \mathrm{~nm}$ absorbans değerleri spektrofotometrik olarak okundu, (Luna ve ark., 2000). Bu ölçümler sonunda yaş yaprak örneğindeki toplam klorofil miktarı aşağıdaki formül kullanılarak $\mu \mathrm{g} / \mathrm{mg}$ taze ağırlık olarak belirlendi. 
Klorofil $=$ Absorbans değerleri x 1000/39.8 x Örnek miktarı

\subsubsection{Total Çözünebilir Protein Miktarının Tayini}

Taze ağırlığı alınan materyal pH 7 fosfat tamponu içinde soğuk havanlarda homojen hale gelene kadar ekstre edildi. Bu yöntemde bir organik boyar madde olan Commassie brillant blue G-250'nin proteindeki renklendirme özelliğinden yararlanılır. Commassie brillant blue G-250, negatif yüklü olan ve proteindeki (+) yüklü gruplara bağlanan bir boyadır. Boya, kırmızı (Amax=465 nm) ve mavi (Amax=595 nm) formlarda bulunur. Kırmızı form çözeltideki halidir, boya proteine bağlanınca mavi renk oluşur. Reaksiyon oldukça tekrarlanabilir ve hızlıdır. İki dakika içinde renk oluşur ve bir saat kadar stabil kalır (Robyt and White, 1987). Bradford yöntemi ile protein tayini yapılırken aşağıdaki işlemler uygulanmıştır.

2.2.5.1. Commassie Brilant Blue G-250 çözeltisinin hazırlanması: $100 \mathrm{mg}$ Commassie Brilant Blue G-250, 50 mL \%95'lik etanolda çözüldükten sonra üzerine $100 \mathrm{ml} \% 85$ 'lik fosforik asit ilave edilmiştir, saf su ile 1L'ye tamamlanmıştır. Karanlıkta 1 gece karıştırılarak beklendikten sonra filtre kağıdı ile süzülerek hazır hale getirilmiştir.

2.2.5.2. BSA (bovine serum albumin): Stok çözeltiden BSA standart eğrisini oluşturmak için tüplere örnek yerine konsantrasyonları belli olan standart çözeltiden (BSA) 1'er ml eklenerek hazırlanmış ve aynen uygulanmıştır. $595 \mathrm{~nm}$ 'de absorbans okutularak konsantrasyona karşı absorbans grafiği çizilir. Şahit çözelti için ise yine örnek yerine $1 \mathrm{~mL}$ saf su koyularak örnek için uygulanan prosedürün aynısı uygulanmıştır. Deney tüpüne analizi yapılacak örnekten $100 \mu \mathrm{L}$ örnek konulur. Üzerine hazırlanan Bradford çözeltisinden $5 \mathrm{~mL}$ eklenerek 5 dakika beklenir. Belirlenen absorbans değerlerinden standart ölçümler kullanılarak toplam çözünebilir protein miktarı belirlenmiştir.

\subsubsection{Prolin Tayini}

Bates ve ark. (1973), göre taze ağırlıkları alınan yaprak örnekleri $10 \mathrm{ml} \% 3$ sülfosalisilik asit içinde homojenize edilmiştir.

2.2.6.1. \%3'lük sülfosalisik hazırlanması: $100 \mathrm{ml} 3 \mathrm{gr}$ tartılıp hazırlanınca $\% 3$ sülfosalisilik asit hazırlanmış olur.

2.2.6.2. Asit-ninhidrin hazırlanışı: $30 \mathrm{ml}$ glasiyal asetik asit içine $1.25 \mathrm{~g}$ ninhidrin'in tartılıp konulur ve üzerine $20 \mathrm{ml} 6 \mathrm{M}$ Fosforik asit eklenir, çalkalanarak çözünene kadar serin $\left(4^{\circ} \mathrm{C}\right.$ 'de 24 saat kalır.

Dondurulmuş bitki materyali, \%3 sulu sülfosalisilik asit $(0.01 \mathrm{~g} / 0.5 \mathrm{ml})$ ilave edildi ve tortu $12000 \mathrm{~g}$ 'de santrifüjle $10^{\circ} \mathrm{C}^{\prime} \mathrm{de} 20$ dakika kalır. Homojenleştirilmiş dokunun $1 \mathrm{ml}$ 'si $1 \mathrm{ml}$ asit-ninhdrin ve $1 \mathrm{ml}$ glasial Asetik asit ile bir test tüpünde $100{ }^{\circ} \mathrm{C}^{\prime}$ de 1 saat süreyle reaksiyona sokulur ve reaksiyon bir buz banyosu ile sona erdirilir. Reaksiyon karışımı, 2 ml toluen ile özütlenir, kuvvetli bir şekilde karıştırılır ve oda sıcaklığında iki faz ayrılıncaya kadar 30 dakika karıştırılır. Prolin konsantrasyonu, L-Prolin kullanılarak standart bir eğriden belirlenir. Reaksiyon ortamına $1 \mathrm{ml}$ toluen ilave edilerek karıştırıldıktan sonra Toluen kör olarak kullanır ve üst sıvı alınarak küvetlerde $520 \mathrm{~nm}$ de ölçülmüştür. Standart olarak L-prolin kullanılıp sonuçlar $\mu \mathrm{mol}$ prolin/g.T.A. olarak hesaplanmıştır.

\subsection{Değerlendirmenin Yapılması}

Deneme, tesadüf parselleri deneme desenine gmre 3 tekerrürlü ve her bir parselde 15 bitki olacak şekilde kurulmuştur. Denemede elde edilen veriler Duncan çoklu karşılaştırma testine tabi tutulmuş, uygulamalar arasındaki farklılıkların istatistiksel açıdan önemlilik derecesi ortaya konulmuştur. Bunun için, SAS (1985) paket programından yararlanılarak Duncan çoklu karşılaştırma testi yapılmış ve farklılık dereceleri, \%0.5 düzeyinde harflendirme yoluyla gösterilmiştir.

\section{Bulgular}

PEG 6000 uygulanarak kuraklık stresi uygulanan biber bitkilerine ayrıca SNP ve SNP ile birlikte c PTIO ile ön uygulama yapıldığında biber bitkilerindeki kuraklık stresine olan tepkiler incelenmiştir (Çizelge $1)$. 
Çizelge 1. Uygulamaların toplam bitki ağılı̆̆ $(\mathrm{g})$ ile yapraklarındaki Protein $(\mu \mathrm{g} / \mathrm{ml})$, Prolin $(\mu \mathrm{mol} / \mathrm{g}$ YA) ,Klorofil ( $\mu \mathrm{g} / \mathrm{g}$ YA) ve Oransal su içeriği (\%).

\begin{tabular}{lllccl}
\hline Uygulama & Topl.Bit.Ağ. & Protein & Prolin & Klorofil & OSİ (\%) \\
\hline KONTROL & $23,88 \mathrm{~A}$ & $0,188 \mathrm{BC}$ & $0,005 \mathrm{~B}$ & $66,87 \mathrm{C}$ & $79,34 \mathrm{~A}$ \\
PEG & $16,98 \mathrm{C}$ & $0,295 \mathrm{~A}$ & $0,0043 \mathrm{~B}$ & $60,51 \mathrm{C}$ & $59,58 \mathrm{D}$ \\
SNP 0,01+ PEG & $23.79 \mathrm{~A}$ & $0,184 \mathrm{BC}$ & $0,0062 \mathrm{~A}$ & $65,35 \mathrm{C}$ & $66,11 \mathrm{C}$ \\
SNP 1+ PEG & $23,09 \mathrm{~A}$ & $0,115 \mathrm{D}$ & $0,0063 \mathrm{~A}$ & $89,30 \mathrm{~B}$ & $74,43 \mathrm{AB}$ \\
SNP 100+ PEG & $15,98 \mathrm{D}$ & $0,138 \mathrm{CD}$ & $0,002 \mathrm{C}$ & $82,40 \mathrm{~B}$ & $71,89 \mathrm{~B}$ \\
C.PTIO+SNP0,01+ PEG & $18,91 \mathrm{~B}$ & $0,143 \mathrm{CD}$ & $0,0063 \mathrm{~A}$ & $98,82 \mathrm{~A}$ & $75,19 \mathrm{AB}$ \\
C.PTIO+SNP 1+ PEG & $15,48 \mathrm{D}$ & $0,180 \mathrm{BC}$ & $0,0023 \mathrm{C}$ & $85,78 \mathrm{~B}$ & $53,81 \mathrm{E}$ \\
C.PTIO+SNP 100+ PEG & $9,77 \mathrm{E}$ & $0,211 \mathrm{~B}$ & $0,002 \mathrm{C}$ & $81,84 \mathrm{~B}$ & $46,04 \mathrm{~F}$ \\
\hline
\end{tabular}

Aynı sütunda aynı büyük harfi alan ortalamalar arasındaki fark $\mathrm{P} \leq 0.05$ e göre önemsizdir.

Çizelge 1' de kuraklık stresi sonrası bitkilerde yapılan bazı fizyolojik ölçümler verilmiştir. Çizelgeye göre ele alınan bu kriterler istatistik olarak \%5 hata sınırları içerisinde kalarak önemli oldukları saptanmış ve LSD testi sonuçları verilmiştir.

Biber bitkilerine PEG 6000 uygulaması sonucunda bitkilerin toplam bitki ağırlıklarını incelediğimizde uygulamalar arasında farklılıkların olduğu görülmüș, toplam bitki ağırlığı kontrole göre artış gösteren uygulamanın olmadığı, ancak kontrolle aynı istatistik aralığında olan SNP 0,01+PEG ve SNP 1+PEG uygulamaları olmuştur. Diğerleri kontrole göre azalmıştır. En fazla azalma ise C.PTIO+SNP100 +PEG de görülmüştür (Çizelge 1).

Bitkilerin protein aktivitesini incelediğimizde uygulamalar arasında farkl1lıkların olduğu görülmüş, PEG ve C.PTIO+SNP100 uygulamalarında protein aktiviteleri kontrole göre artı̧ gösterirken, , SNP1, SNP 100 ve C.PTIO+SNP0,01 de uygulamalarda ise kontrole göre azalmışlardır. SNP 0,01 ve C.PTIO+SNP 1 ise kontrolle aynı istatistiki grup aralığında bulunmuştur (Çizelge 1).

Biber bitkilerine PEG 6000 uygulaması sonucunda bitkilerin prolin aktivitesini incelediğimizde uygulamalar arasında farklılıkların olduğu görülmüş, C.PTIO+SNP0,01, SNP1 ve SNP 0,01 uygulamalarında prolin aktiviteleri kontrole göre artış gösterirken, C.PTIO+SNP 100, SNP 100 ve C.PTIO+SNP 1 de uygulamalarda ise kontrole göre azalmışlardır. PEG uygulması ise kontrolle aynı istatistikî grup aralı̆̆ında bulunmuştur (Çizelge 1).

Biber bitkilerine PEG 6000 uygulaması sonucunda bitkilerin klorofil değerleri incelediğimizde uygulamalar arasında farklılıkların olduğu görülmüş, C.PTIO+SNP0,01, SNP 1, C.PTIO+SNP 1, SNP 100 ve C.PTIO+SNP 100 uygulamalarında klorofil değerleri kontrole göre artış gösterirken, SNP 0,01 ve PEG de uygulamalarda ise kontrole göre azalmışlardır. SNP 0,01 ve PEG uygulamaları ise kontrolle aynı istatistiki grup aralığında bulunmuştur (Çizelge 1).

\section{Tartışma ve Sonuç}

Farklı dozlarda ön muameleye tabi tutulmuş biber bitkilerinin büyüme ve gelişme parametrelerinden kök, gövde ve yaprak ağırlığı bakımından SNP ve c.PTIO+SNP ile yapılan ön uygulamalarının 0,01 ve $1 \mu \mathrm{M}$ luk dozları kuraklık uygulanmamış kontrol bitkileriyle aynı aralıkta oldukları, ön muamelesiz PEG uygulamasına göre çok daha iyi geliştikleri görülmüştür. SNP ve cPTIO+SNP nin $100 \mu \mathrm{M}$ luk dozu olumlu etki yapmadığı gibi bitkilerin gelişmesi üzerine ön muamelesiz PEG' e göre bitkileri daha fazla strese soktuğu görülmüsşür. Aynı durumlar yaprak sayısı, bitki boyu ve boğum arası bakımından da gözlemlenmiştir. Sekmen ve ark. (2005), de domates bitkisinde tuz stresi uygulayarak yaptıkları çalışmada ön muameleye tabi tutulmuş bitkilerin 28. gündeki kök ve gövde ağırlıkları ile uzunlukları ön muamelesiz tuz stresi uygulanmış bitkilere göre artış gösterdiğini bulmuşlardır. Aynı şekilde Tuna ve Eroğlu (2017), tuz stresi altındaki biber bitkilerine NO ön muamelesi uygulayarak bitkilerin stres altındaki kök gövde ve yaprak ağırlıklarına bakmışlardır. Bitkilerin kök, gövde ve yaprak gelişimleri kontrole göre azalırken ön muamelesiz tuz uygulamasına göre daha iyi geliştikleri tespit edilmiştir.

Yüzde 10 luk PEG 6000 ile kuraklık stresi uygulanmış biber bitkilerinin protein birikimleri bakımından PEG ile kuraklık stresine maruz bırakılmış biber bitkileri SNP ile ön muameleye tabi tutulduklarında kontrole göre azalma olsa bile SNP muamelesine tabi tutulmayan PEG uygulamasından daha yüksek 
proteine sahip olmuşlardır. Fakat PEG ile birlikte SNP 100 ve cPTIO+SNP 100 dozlarının protein birikimine olumlu etkisi olmamıştır. Buradan da görülüyor ki SNP dozları önemli bulunmuştur. En etkili doz SNP 0,01 dozu olmuştur. Sekmen ve ark. (2005), domatese tuz stresi ve ön uygulama yaparak yaptıkları çalışmada, stresin 0. gününde Stubble-Aid aktivatörünün uygulandığı bitkilerin protein miktarı kontrol bitkilerine göre \%21'lik bir artış olduğu görülmüştür. Kireçci (2012), hassas ve tolerant buğday çeşidine kuraklık ile birlikte farklı dozlarda SNP uygulayarak yapmış olduğu çalışmada PEG ile birlikte SNP nin en düşük dozu olan $10 \mu \mathrm{M}$ da protein birikimi en yüksek düzeyde bulunmuş, SNP nin dozu arttıkça100 $\mu \mathrm{Mda}$ protein birikiminde düşüş olmuş, en düşük protein birikimi $1000 \mu \mathrm{M}$ SNP dozunda olmuştur. Benzer şekilde Mohammadkhanı ve Heıdarı (2008), kuraklık stresi uyguladıkları mısır bitkisinde, Liu ve ark. (2011), soğuk stresi uyguladıkları hıyar (Cucumis sativus L.) bitkisine dışsal olarak uyguladıkları SNP'nin düşük konsantrasyonlarda toplam çözünebilir protein miktarında artış, yüksek konsantrasyonda ise azalıș meydana getirdiğini bildirdikleri çalışmalar da bizim yaptı̆̆ımız çalışmadan elde ettiğimiz sonuçlarla uyum göstermiştir. Diğer parametrelerde olduğu gibi c.PTIO nun SNP ile birlikte bitkilerin ön muamelesinde kullanılmasının olumlu etkisi olmadığı gibi olumsuz etkisinin olduğunu söylemek mümkündür. Çünkü SNP 0,01 dozu ile SNP $1 \mu \mathrm{M}$ dozları tüm parametrelerde kuraklık zararını önleyici etkisinin olduğu görülürken, c.PTIO+SNP1+PEG uygulamasında kuraklık zararını önlemediğini görmekteyiz.

Kuraklık uygulaması ile bitkilerin oransal su içerikleri bakımından kontrol uygulaması en yüksek değerde bulunmuş, onu c.PTIO + SNP 0,01+PEG uygulaması ile SNP 1 + PEG uygulaması almıştır. En düşük değerler ön muamelesiz PEG den sonra c.PTIO + SNP 1+PEG ve c.PTIO + SNP 100+PEG olmuştur. Burada da c.PTIO ların pozitif etkisinden ziyade negatif etkilerinin olduğu görülmektedir. SNP nin 0,01 ve $1 \mu \mathrm{M}$ luk dozlarının pozitif etki ettiği $100 \mu \mathrm{M}$ luk dozunun pekçok parametrede negatif etki yaptığı görülmesine karşın OSİ de kontrole göre az olmasının yanında orta düzeyde bulunmuştur. Yapılan çalışmalarda benzer sonuçlar elde edilmiştir (Kireçci, 2011). Kuraklığa hassas ve tolerant iki çeşitle yaptığı çalışmada kuraklığa dayanıklı çeşidin yüksek seviyede OSİ ne sahip olduğunu ve SNP'nin bunda etkili olduğunu, SNP nin de dozlarının önemli olduğunu yüksek dozlarının olumlu etkiye sahip olmadığını belirtmiştir. Kurağa tolerant olan bitkinin kuraklık stresi koşullarında aşırı su kaybından kaçınmak amacıyla transpirasyon oranını kontrol altında tuttukları ve hücre içinde prolin gibi organik asitlerin birikimin artırdıkları düşünülmektedir. Sairam ve ark. (2000), farklı buğday genotiplerine uyguladıkları tuz stresinden, Kulkarni ve ark. (2010), Ziziphusmauritiana ya kuraklık stresi uygulanarak yaptığı çalışmada benzer sonuçlar elde etmişlerdir. Tian ve Lei. (2006), yaptıkları çalışmada; SNP ve cPTIO kullanarak dışsal NO’nun ozmotik stres uygulanmıştır. Bitkilere uygulanan SNP yapraklardaki su kaybının azalmasını engellemiş ve dolayısıyla oransal su içeriğinin yüksek olmasını sağlamış ve bu durumun yüksek prolin içeriğine neden olduğunu belirtilmişlerdir. Bunun yanında SNP'nin bu etkilerinin cPTIO ile tersine çevrildiği sonucuna varılmıştır. Sonuçlardan NO’nun buğday yapraklarında ozmotik stresin neden olduğu spesifik hasarları engellediği rapor edilmiştir. Zhao ve ark. (2008), yaptıkları çalışmada NO, oksit süpürücüsü olan cPTIO’nun, SNP'nin aracılık ettiği korunmayı bloke ettiği belirtilmiştir. Ön muamelesiz PEG uygulaması ile kıyaslandığında cPTIO tarafından içsel NO’nun tüketildiğinden ve oksidatif strese neden olduğundan bahsedilmiştir.

Biber bitkilerine PEG 6000 ile uygulanan kuraklık stresinin etkisinin azalıp azalmayacağını anlamak için kuraklık uygulanmadan önce NO vericisi olan SNP ve cPTIO uygulanmıştır. Bu uygulamalar sonucunda SNP 0,01 + PEG, SNP 1 + PEG ve SNP 0,01 + cPTIO + PEG uygulamalarında kontrole göre daha yüksek klorofil birikimine sahip olmuşlardır. SNP nin yüksek dozu kontrolden daha düşük klorofil miktarına sahip olmuştur. Diğer parametrelerde olduğu gibi klorofil miktarının artışına cPTIO nun olumlu etkisinin olmadığı görülmüştür. Farklı araştırıcıların farklı bitkilerde yapmış oldukları çalışmalarda benzer sonuçlar elde etmişlerdir. Lei ve ark. (2007), yaptıkları çalışmada, 0,2 mM SNP ön uygulamasının buğday filizlerinin büyümesini geliştirdiğinin yanında, bitki yapraklarındaki toplam klorofil miktarını artırdığını ve NO’nun ozmotik stresin azaltılıp azaltılmamasının uygulanan SNP konsantrasyona bağlı olduğunu belirtmişlerdir. Tuna ve ark. (2017), biberde yaptıkları tuz stres uygulamasında, $\mathrm{NaCl}+\mathrm{NO}$ uygulamasını ön uygulamasız $\mathrm{NaCl}$ uygulaması ile kıyaslandığında toplam klorofil içeriğinde \%34 civarında bir artışın olduğu görülmüştür. Kuraklığa bağlı olarak bitkilerin fotosentetik elektron transferi ve klorofil miktarlarında azalmaların olduğu daha önceki yapılan çalışmalarda da belirtilmiştir ( Fu ve Huang, 2001; Türkan ve ark., 2005; Yaşar ve ark., 2008a; Yaşar ve ark., 2010).

Sonuç olarak, SNP uygulamasının bitki gelişimini artırdığı ve yüksek oranda su içeriğinde artışa sebep olması demek hücre içindeki organik asitlerin oranında artışların olduğunu ve bitkinin normal gelişim metabolizmasını devam ettirdiğinin göstergesi olabileceği kanısındayız. 


\section{Kaynaklar}

Anjum, SA., Xie, X., Wang, L., Saleem, MF., Man, C., Lei, W., 2011. Morphological, physiological and biochemical responses of plants to drought stres. African Journal of Agricultural Research, 6: 2026-2032.

Bates, L.S., Waldren, R.P., Teare, I.D., 1973, Rapid Determination of Free Proline for WaterStress Studies, Plant Soil, 39, 205-207.

Carlos, G.M., Lorenzo, L., 2001. Nitric Oxide Induces Stomatal Closure and Enhances the Adaptive Plant Responses against Drought Stress. Plant Physiology, 104, 1015-1025.

Farrant J. M., 2000. A comparison of mechanisms of desiccation tolerance among three angiosperm resurrection plant species, Plant Ecology, 151: 29-39.

Ferrer, M.A., Ros-Barcelo', A., 1999. Differential Effects of Nitric Oxide on Peroxidase and H20 2 Production by The Xylem of Zinnia Elegans. Plant Cell Environ Journal, 22, 891-897.

Fu, J., Huang, B., 2001. Involvement of antioxidants and lipid peroxidation in the adaptation of two cool-season grasses to localized drought stress. Environmental and Experimental Botany, 45: 105114.

Garcia-Mata, C., Lamattina, L., 2001. Nitric oxide induces stomatal closure and enhances the adaptive plant responses against drought stress. Plant Physiology, 126, 1196-1204.

Hung, K.T., Kao, C.H., 2003. Nitric Oxide Counteracts the Senescence of Rice Leaves Induced by Abscisic Acid. Journal of Plant Physiology, 160 (8),871-879.

Kireçci O.A., ve Yürekli F., 2011. The relationship between nitric oxide and plant. Acephala Dc, Acta Bıologica Hungarica, vol.62, pp.463-476.

Kireçci, O.A., 2012. Kuraklı Stresine Maruz Bırakılan Triticum aestivum L. (Buğday) Çeşitlerinde Sinyal İletiminde Rol Oynayan Bazı Biyomoleküllerin Araştırllması, İnönü Üniversitesi Fen Bilimleri Enstitüsü doktora tezi.

Kishor, PB., Sreenivasulu, N., 2014. Is proline accumulation per se correlated with stress tolerance or is proline homeostatis a more critical issue? Plant Cell Environ., 37: 300-311.

Kulkarni, M., Schneider, B., Raveh, E., Tel-Zur, N., 2010. Leaf anatomical characteristics and physiological responses to short-term drought in Ziziphus mauritiana (Lamk.) Scientia Horticulturae, Article in press, 124: 316-322

Lei, Y., Yin, J., Li, C., 2007. Effects of osmotic stress and sodium nitroprusside pretreatment on proline metabolism of wheat seedlings. Biologia Plantarum 51 (2):386-390.

Leshem, Y.Y., Haramaty, E., 1996. The characterization and contrasting effects of the nitric oxide free radical in vegetative stress and senescence of Pisum sativum Linn. foliage. Journal Plant Physiology, 148, 258-263.

Liang, X., Zhang, L., Natarajan, SK., Becker, DF., 2013. Proline mechanism of stress survival. Antioxidants Redox Signaling, 19: 998-1011.

Liu, X., Wang, L., Liu, L., Guo, Y.g., and Ren, H., 2011. Alleviating effect of exogenous nitric oxide in cucumber seedling against chilling stress. African Journal of Biotechnology Vol. 10 (21), pp. 4380-4386.

Luna, C., Seffino, L. G., Arias, C., ve Taleisnik, E., 2000. Oxidative Stress Indicators as Selection Tools for Salt Tolerance in Chloris gayana.. Plant Breeding. 119: 341-345. 
Mohammadkhani, N., Heidari, R., 2008. Effects of drought stress on soluble proteins in two maize varieties Turkish Journal of Biology, 32, 23-30.

Murgfa, L., Delledorme, M., Soave, C., 2002. Nitric Oxide Mediates Iron-Induced Ferritin Accumulation in Arabidopsis. Plant Journal, 30, 521-528.

Olson, SY., Garban, HJ., 2008. Regulation of apoptosis-related genes by nitric oxide in cancer. Nitric Oxide 19: 170-176.

Robyt, J. F., White, B. J. 1987. Biochemical Techniques: Theory and Practice. Brooks/Cole, Monterey, CA.

Sairam, R.K., Rao, K.V., Srivastava, G.C., 2002. Differential response of wheat genotypes to term salinity stress in relation to oxidative stress, antioxidant activity and osmolyte concentration. Plant Science, 163:1037-46.

SAS., 1985. Sas/State User's Guide 6.03 ed. SAS. Ins. Cary. N.C.

Sekmen, H., Demiral, T., Tosun, N., Türküsay, H., Türkan, İ., 2005. Tuz Stresi Uygulanan Domates Bitkilerinin Bazı Fizyolojik Özellikleri ve Toplam Protein Miktarı Üzerine Bitki Aktivatörünün Etkisi. Ege Üniversitesi Ziraat Fakültesi Dergisi, 42(1):85-95

Taiz L, Zeiger E., 2010. Responses and adaptations to abiotic stress. In: Plant Physiology, Fifth Edition. Sunderland, MA: Sinauer Associates, Inc. pp. 755-778. ISBN 978-0-87893- 866-7928

Tian, X., Lei, Y., 2006. Nitric oxide treatment alleviates drought stress in wheat seedlings. Bıologla Plantarum 50 (4):775-778.

Tuna, A. L., Eroğlu, B., 2017. Tuz stresi altındaki biber (Capsicum annuum L.) bitkisinde baz1 organik ve inorganik bileşiklerin antioksidatif sisteme etkileri. Anadolu Tarım Bilimleri Dergisi/ Anadolu Journal of Agricultural Sciences, 32 (2017) 121-131.

Türkan, İ., Bor, M., Özdemir, F., Koca, H., 2005. Differential responses of lipid peroxidation and antioxidants in the leaves of drought-tolerant P.acutifolius Gray and drought-sensitive $P$. vulgaris L. subjected to polyethylene glycol mediated water stress, Plant Sciences, 168: 223-231.

Yaşar, F., Ellialtioglu, Ş., Yildiz, K., 2008a., "Effect of salt stress on antioxidant defense systems, lipid peroxidation and chlorophyll content in green bean (Phaseolous vulgaris L.), Russian Journal of Plant Physiology, 55 (6): 1-5.

Yaşar, F., Uzal, Ö., Özpay, T., 2010. Changes of the lipid peroxidation and chlorophyllamount of green bean genotypes under drought stress, African Journal of Agricultural Research Vol. 5(19), pp. $2705-2709$

Yaşar, F., Üzal, Ö., Köse Ş., Yaşar, Ö., Ellialtioglu, S., 2014. Enzyme activities of certain pumpkin (Cucurbita spp) species under drought stress, Fresenıus Envıronmental Bulletın, vol.23, pp.10931099.

Zhao, H., Tan, J., Hong, J., Han, Y., Li, H., Zhao, W., 2008. Effects of exogenous nitric oxide on photosynthesis, antioxidant capacity and proline accumulation in wheat seedlings subjected to osmotic stress. World Journal of Agricultural Sciences, 4 (3):307-313. 